\title{
Towards a polyphonic urban score
}

\author{
Lidia Decandia
}

\begin{abstract}
Background: By drawing on literature from various disciplinary fields, in particular branches of geography, philosophy, urban design and planning, the article investigates the deep spatial transformations affecting cities and territories. As this variety of reading seems to point out, we increasingly encounter space that is replacing the sharpness of figures of definite boundaries, the hierarchies and regularity, the oneness and coherence with a tangled, vibrant territoriality that is continuously shifting and difficult to map out following the criteria by which we have been used to giving order to the world. Space made up of different situations in which the old dichotomies centre/edge, city/country, local/global, nearness/distance, inside/out, public/private and real/virtual disappear and disintegrate, and in which the invisible and the immaterial return to populate the world.

Methods: Starting with an acknowledgement of these deep changes and the sense of bewilderment they arouse in us, the article invites us not to take refuge in horizons already known or to try to recompose by creating simulacra the members of a dead body of a city and territory that no longer exist. It proposes instead new explorative methods with which to investigate and above all give expression to the materials, needs, the urgency and qualities that characterise this new widespread urban condition belonging to us. It invites us not to consider the territory like a white board upon which to impose forms, but to pay attention to memories, strengths and energies that cannot be seen but which work uninterruptedly to produce change.

Results: It is indeed by starting from an acknowledgement of these qualities that produce different kinds of territoriality and cannot be standardised on a single plane, that the article suggests it is possible to give shape to an original composition, able to "artistically" express a new urban culture.

Conclusions: By taking inspiration from the concept of polyphony, borrowed from music, it invites us not to standardise these diversities in a single time or on a single plane, but to use them to give life, through "weaving" and "mending" tasks, to an original composition: a polyphonic composition, in which the different qualities of the parts, though developing autonomously, can play simultaneously, so as to produce an unprecedented urban sound. A sound in which it is the contraction and expansion of spaces, the alternation of full and empty elements, the flights and refrains, deserted places and high intensity nodes that will determine the rhythmic course of the form.
\end{abstract}

\section{The emergence of new spatialities}

One of the beliefs of many disciplines is that the idea of city, and above all the idea of urban that we have associated with it for centuries, is undergoing deep, irreversible changes. As researchers are discovering, a great variety of new ways of living and inhabiting, of moving through and across space, which transcend administrative and political borders, appear in fact to be sketching out new geographies and making new original and

\section{Correspondence: lidia.decandia@gmail.com}

Dipartimento di Architettura, Design, Urbanistica, Università degli Studi di Sassari, Palazzo del Pou Salit, Piazza Duomo (via Manno) 6, Alghero 07041, Italia complex spatialities emerge and multiply (Lefebvre 1968; Dematteis 1988; Choay 1994; Serres 1993; Foucault 1994; Nancy 1999; Amin and Thrift 2002; Sassen 2006, Sassen 2012; Soja 1989).

As technological innovations, new social and productive organisations and new political systems break down the old systems and ancient hierarchies, they cause an idea of space and a way of using time to emerge that are completely different from those of the past.

We are having to cope with space that is increasingly fragmented, heterogeneous and difficult to map out if we use the old categories with which we attempted to harness the world. Space that is less and less like a

\section{Springer}


surface easily measured, in which the old boundaries are dispensed with and shrivel up, and where the old dichotomies - centre/edge, city/country, local/global, closeness/remoteness, inside/out, real/virtual, public/private - seem to be crossbreeding and blending in a melting-pot ever more difficult to understand.

The city itself, if considered as a delimited, circumscribed entity, a pivot around which the entire territory is organised, has expanded into myriad spaces difficult to enclose within an edge or boundary. Apart from the forms, it is the actual content that has exploded and leapt out of the city, to be distributed on a territory that seems more and more to welcome these splinters and dust spread in completely original forms compared with the past.

\section{The invisible and the immaterial repopulate the world}

Although the topographical and physical concentrations continue to exist that identified the city as we have known it, just as in some cases landscape forms created in the country by human intervention continue to last, in actual fact it is the methods of use and the forms of symbolic appropriation themselves that are deeply changing meanings (Donadieu 1998; Dal Pozzolo 2002). If, up to a short time ago, anyone looking at the territory from an aircraft above could imagine, by reading and interpreting signs and physical forms, the social functions and organisation of which they were evidence, in these last decades it would be really difficult to understand, by reading these superficial signs, the life hidden beneath the fake images of appearances.

Often, what we see is not actually anything more than the simulacrum of something that no longer exists but appears through its image to make an absent object present and in some way to cover up its actual death (Marin 1994). The visible signs and material topographical features that assured us of the presence of precise organisational methods underway seem, in fact, to be turning into remains or empty carcasses that no longer manage to "tell us anything plausible or concrete about how the world is functioning" (Farinelli 2003 p. 53). The invisible and the immaterial return indeed to peep through, as they increasingly swallow up the economy, information, sociality and production (Farinelli 2009).

New flows boldly reconfigure the relations between men and the different places of the earth re-enchanting, at least from a functional point of view, the world Modernity had disenchanted. "A sort of invisible city is progressively replacing or putting into second place the physical, figurative one" (Branzi 2006, p. 12). Profound changes, progressive and not very obvious, often developing out of sight, are actually causing deep general transformations that are not evident.
The vision upon which we have nurtured our faith in knowledge for centuries is no longer enough on its own to provide us with the instruments necessary for us to grasp the meaning of the changes underway (Decandia 2008).

\section{Topologies: a dense, variegated and rugged surface}

On the territory that is emerging space takes on articulate, complicated connotations: "more mixed than pure, not so much smooth and homogeneous as changing, harlequin, zebra-striped and in multiple, connected networks" (Serres 1993 p. 270). Essentially Euclidean geometric space of lines, points and surfaces is being challenged: the relations between the different points of the space, no longer entrusted to certain privileged channels, are being rearranged in a huge variety of possible ways, via reciprocal, non-symmetrical correlations. This "intensive striping of space" seems to be making a polymorphous, changing reality re-emerge, with extraordinarily subtle topological features, no longer based on points or objects but on haecceities, on groups of relations (...) A space that is tactile much more than visual. A space occupied by events or haecceities. A space of ties rather than properties (Deleuze and Guattari 1980, p. 696).

This random space, discontinuous and heterogeneous, shows itself as a surface on which spatio-physical events, moving at different speeds, belong to kinds of time and space that can no longer be united with each other. Within an area of a few square kilometres, often on the horizon of the same locality, we can witness full-scale pluri-secular gaps: situations existing side by side that refer to extremely different time frames; technicians of the advanced tertiary sector side by side with shepherds, robotised industries with flocks of sheep, places where time seems on the one hand to have come to a halt while, on the other, it seems to be synchronised with the clocks of Silicon Valley.

The notion of contemporaneity itself, precisely because it seems to crush time into a flat, simultaneous dimension, is no longer sufficient to express this mixing, intersecting and diversifying of time that is modelling the territory (Didi-Huberman 2000; Agamben 2008).

\section{Simulacra to protect us from the chaos}

As the changes underway emerge, the filters and perceptive grids with which we have attempted to give order to the world do not help us to understand and harness something that surpasses the idea of space and, above all, the notion of city we have become used to.

Permeated by perspective visual thought and accustomed to reading the city like a text that can be subjected 
to a single gaze, our culture no longer manages to grasp the sense of this new, absurd, elusive geography.

It is difficult not to feel a sensation of loss and disorientation when confronted with a landscape that seems to be breaking up; where the familiarity and solidity granted it by our habitual gaze is shocked by presences that go beyond our capacity for understanding, appal us and leave us breathless. We feel sucked up, swallowed, entangled and baffled by this absence of form.

The emergence of spatial multiplicity that is difficult to depict disorganises our perceptive field, glistens everywhere, causing our visual viewpoint to break into fragments. No longer controllable from that geometrical point of view, it takes power away from the prospective eye, blind and rational, on which we have based our gaze and harnessed and captured the world.

And it is then, precisely to elude this feeling of anguish and disorientation that invades us when faced with the unprecedented, the unforeseen imposing its presence along the wayside - impossible for us to master with the instruments the conscience can filter - that we try to find refuge in something we already know, to fit things into the foreseeable and deny reality, destroy what our sight does not master (Berto 1999). Instead of looking for new figures to give shape to these dynamic, vital realities that involve us and close in on us, evading any kind of portrayal, we prefer, on a drawing board, to reassemble the broken limbs of a dead body that no longer exists. We carry on constructing, with those old patterns we inherited from the past, maps and pictures of cities lacking life, frozen in an instant, to then place them down on dumb territories we are incapable of listening to.

And yet this sense of bewilderment is not new: man's alienation in coping with a world he does not know has always been a source of crisis and anxiety. This is why from the beginning, and in different cultural contexts, man has always needed to find fixed points that would enable him to get his bearings in the homogeneousness of the chaos (Eliade 1965).

Nevertheless, it is not by turning to the city idea that we have known, or feeling nostalgia for past architecture but, rather, by accepting that this phase of bewilderment has to be surpassed, that we can regenerate our perceptive capacities and renew the gaze with which we usually grasp what is considered as unknown. Perhaps then, instead of retreating into nostalgia and regret or languishing in resentment, we should commit ourselves to resisting and defending lost values. We need to rise to the challenge posed by the new ways of considering settlement space, and transform this chaos we feel we are immersed in into a cosmos in which we can identify ourselves and of which we feel a part.

To do this, however, it is not enough to replicate lost orders or superimpose an "external machinic order" separate from the present then placed onto the territory, but we must start indeed from the unattainable, inexhaustible reality that belongs to us, which, by virtue of this, still today constitutes the reserve of meaning from which each act of creation proceeds (Deleuze 1981).

\section{Perforating the skin of things}

To contend with this unattainable reality means therefore to go beyond apparent forms, widen the boundaries of our gaze: "perforate the skin of things, to see how things become things and the world becomes world" (Merleau Ponty 1964, p. 49); "leave aside everything that prevents us from seeing, all the passed-on ideas, the preconstituted images that continue to encumber our visual field and capacity for understanding" (quoted by Barenghi, Calvino 1992, p. 346).

To give shape to this contemporary magma we might say, paraphrasing Deleuze, that preparatory, silent work is needed, able to break with supreme optical organisation and to clear away and clean up the given clichés of shapes to enter into contact with and reveal "the body that is beneath the organism, that makes organisms and their elements break up or explode" (Deleuze 1981, p. 232), which "forces them to suffer spasms, puts them into relations with forces, be they internal, that raise them up, or external, that pass through them, or eternal, of time unchanging, variables of time that flows on" (ib.), "becoming aware of being there", "grasping forces (...) making visible forces that are not" (Deleuze 1981, p. 117). "Making time and the strength of time visible" (p. 125) and painting the unexpressed picture that has not yet managed to come to light".

So we can no longer be satisfied with seeing just what can be seen by gazing and at a distance, but we need to get closer to things again; enter inside the territory; rediscover its variegated density and range of populations. A density that cannot be understood from afar, remaining in those towers from which we believed we could learn about the world, but only grasped if we manage to immerse ourselves in the living body of its flesh so as to begin an authentic exploration of the urban landscape that belongs to us.

It is a landscape consisting of fluffy filaments, of gaps and filled parts, concretions of pieces of ancient cities and deserted, silent spaces. Pieces that draw near to each other moving at different rhythms and in different ways, which contemporary man is recovering possession of, reusing, modifying and renewing the immobile containers from the inside and giving new immaterial meanings to the deserted, silent spaces by weaving new relations once more between the parts with invisible threads.

To start again from this exploration and imagine a new form of urbanity means to become aware that we are dealing not with a white board on which to let forms 
settle but, if anything, with a highly diversified space, continuously in motion, with various layers and levels, in which 'wiring' propels energies and forces that are not seen but work uninterruptedly to produce incessant change. And it is with this latency that we have to deal.

\section{Towards a polyphonic score}

It is indeed on the basis of the acknowledgement and enhancement of this space, made up of a large number of diversified situations moving at different speeds and in different ways, that it will be possible to imagine a new kind of city. A city in which these diversities are not reduced or standardised on a single plane or time frame but, rather, enhanced and arranged in a brand new urban composition.

Instead, therefore, of thinking of a city that expands according to a single model - a simplified sound, a monody ${ }^{\mathrm{a}}$ in fact - we might imagine taking a cue from music and working to create an authentic polyphonic composition $^{\mathrm{b}}$. One in which the diverse qualities of the parts could develop autonomously following their own melodic strain, yet play together simultaneously, in a dialogue with each other following a precise construction able to produce general harmony, characterised by a precise melodic and rhythmic plan.

We should therefore start by recognising the different sounds that exist and compose and create a new fabric in which the old cities, the built nodes, can become in a certain sense the components of a wider system. A system in which it is precisely the alternation and juxtaposition of different qualities that produces the rhythmic movement of the shape of a more complex kind of urbanity. A kind of authentic musical score in which there is space for sonorous moments to exist simultaneously, for full and empty elements to be brought together, swelling and pauses, slow and quick parts, deserted places and high density nodes.

A rhythmic composition in which the clearer, more acute "soprano" voices of the ancient cities, easier to perceive immediately, may have as a background the low voices of the areas with a greater natural component, but also the voices of "tenors and contraltos" of the rural areas and the smallest settlements: more ambiguous half voices - able to keep the different parts together and develop the harmonic prerequisites of the stylistic code and phraseological nature of this new urban place. Precisely because this original urban structure is part of a new system of relations, the "empty" spaces of silence within it could also take on "the contours of a simple detail... to lose some of their traits and adopt surprisingly new ones (including the urgency of being listened to at last)" (Corzani 1994, p. 167), rather than being relegated to narrating marginality.

These areas, forgotten and emptied by modernism, could in effect become precious resources, the sacred spaces of renewed urbanity, counter-spaces of a new urban geography. Voids where recharging stations can be spread, distributors of energy that will allow contemporary man, sick of speed, to stop and listen to the silence and collect his thoughts to regenerate himself.

Perhaps, as Wenders ${ }^{c}$ teaches us in an old but beautiful film of his, it is actually in these voids, where all dreams have not yet been realised, that contemporary man, sick of speed and of the inability to stop and rest, might find, alternating between the various time frames, those pauses and gaps that will let him begin to see again. Then precisely in these places might he be able to begin again to establish a different relationship with men and things, more friendly and with greater faith; go back and take lessons from nature, look at a blade of grass to feel himself like it; abandon the abstractness of Euclidean surfaces to start experiencing physicality again; slow down to be able to see what he misses by rushing; rediscover minimal details, nuances, small signs, the changes that denote differences, the smallest appearances, tenderness, intensity, all crushed by speed; but also give back space to the symbolic, sacred and imaginary dimensions able to give voice to what has been removed, the unruly, to corporality, and to everything that is not dominated or controlled.

\section{Acknowledging and producing differences}

The creation of this score entails complex research and project work able to take place at various scales and levels. On the one hand, diversities need to be acknowledged and produced. As for all good polyphony, each voice and each setting must in effect have an evolving dynamic autonomy of its own. Hence, it is not enough to confine ourselves to a simple attitude of conservation which would risk transforming contexts produced by the relations men have established with their life environments into standardised, over-refined "images", the skin detached from the fruit, but we need to continue letting each context be the expression of creative production.

To do so co-evolutionary contexts need to be built in which the various subjects inhabiting and travelling over the various territories can be involved in a return to being active protagonists of the building of their own destiny (Decandia 2000). Interactive contexts of relational learning which, by working "poetically" and "molecularly", putting the memory box back into contact with that of dreams, and using vital forms of rationality and languages capable of appealing not only to the intellect but also to the senses, to open up affective, vital relations with places once more and to produce, make dynamic, put into circulation and socialise a collective intelligence to which the capacity to cultivate and take care of the different qualities of territories could once again be entrusted. 


\section{Working on relations}

If, in order to create this original urban composition, it is important to work in the different territorial contexts, it is just as important to construct, alternating between the various scales, new forms of relation and connection between the different parts of the territory.

What needs to be done, in fact, is to transform this cacophony and fragmented juxtaposition of pieces inherited from modernism into a score that will be able to make the city converse and reassemble in a new harmonic figure 'in the making' spread weakly over the territory.

Those who thought up the Harlequin costume, inventing one of the most famous masks of the Italian comedy theatre, knew well that it took imagination for those different patches to be used together to create a new costume. And they also knew that the moment the costume took shape those same scraps, initially simple remnants, acquired new value, as they were integrated into an original composition. One that did not cancel out the preceding parts but instead absorbed them, organically and totally recreating a new pattern with them, bringing them to life again and enhancing them while keeping them together in a shape endowed with a new "principle of order and meaning". Thus, in the same way as birds and fish build "their territory" using colour expressively, and even urine and excrement, by reabsorbing and transforming them through expressive action, we also need to make different parts work together to try and construct original territoriality together. As Deleuze and Guattari remind us, it is not actually simple functional use but rather the emergence of expressive materials that defines the territory (Deleuze and Guattari 1980).

Perhaps, in order to develop a new score starting with the sounds that exist, we should give up an absolute, globalising plan, a glance from above, to work initially through juxtaposition. For rather than building we should actually think of a detailed, widespread task of sewing and mending which, by taking the ancient arts of weaving and braiding as a model, will succeed in reusing and reassembling in a new fabric the old parts of the territory we have inherited.

In order to do this we should learn to work not so much on objects and things as, above all, on relations: build up a weft of services and pliable networks, ready to be continuously transformed; work more on the software of the territory than the hardware (Branzi 2006); produce a sort of circuit that will enable links to be increased and numerous live connections to be established between highly diverse situations.

Our work should no longer follow the logic aimed at "finding a box for each thing" that has led us to operate by cutting, separating and creating boundaries that distinguish enclosed, impermeable territories, to begin thinking of a widespread filigree in which both territories and "pliable, deformable spaces, spongy and 'molluscular' may be placed, able to accommodate and penetrate each other. It is not a case of an operation to suppress boundaries: any entity presents boundaries or it would be destroyed. Nor is it a case of anarchically muddling up relations between the different times of the different places. It is more a matter of granting without muddling, letting the whole live in the quality of each part" (Cacciari 2004, p.58).

If, after the success of the perspective paradigm, we have argued for our territory more and more in terms of points and lines, now we must begin again to deal with the complexity of a much more amorphous, complex, juxtaposed space; go beyond the simple, flattened vision with few dimensions and reflect on the development of territoriality produced by a multiplicity of circuits and exchanges between heterogeneous cultural and environmental varieties, in which the flows of information between the different parts may be reconsidered in new ways.

We therefore need to imagine a territory where the infrastructures themselves are no longer thought of as simple channels, lines linking one point with another and where what is in the middle appears as "separate, opaque and distant". We must start instead to conceive of a plural kind of spatiality, extended, expanded, rediscovered in the wealth of its otherness and the nuances of its differences, and nurtured by an articulate, complex system of material and immaterial infrastructures that penetrate a territory no longer marked by boundaries but by open filters (Branzi 2006). "Porous sponges" (Secchi 2000), relational flows and units able to ramify organically to the point of becoming weak and uncertain, capable of allowing different modulations of access, permitting the passage from speed to slowness, and dealing with the richness of concave and convex spaces. A weak, light connective system, made up of new, sophisticated technologies able to adapt to the trends of the different territories and to the diversified temporal modulations composing it, nearer to the energies and models of nature than to the mechanical devices of the old modern technology.

A system that will enable, by constructing time exchangers, passages, relational junctions, accumulations, gaps and pauses, a way through an articulate, multifaceted intricacy of differentiated situations.

\section{Refrains and centralities}

Within this bustling polyphonic space together with the filigree of connections, by means of which the pieces of this new fabric can be stitched back together, new forms of pliable centralities need to be created. Precisely so that cities may become one of the many pieces in the mosaic, almost like rocky peaks emerging from a landscape with changing borders built up of diversified situations, we need to delve through and explore places 
dispersed on the territory where life may already be at work, fractures in which suggestions are already present, hints of new spaces of interaction and relations. And we must work in these interstices, scattered poles of production and of energy accumulation, in order to strengthen them, have services coagulate in them and build up conditions capable of triggering other open situations of conviviality.

As Villani observes: "the fortress city and the logic of segregation need to be countered by an urban life that contrasts with the existing kind, split into free pathways of encounters in which time, the 'spending' of time is not commensurate with consumption. Musical spaces with endless variations capable of re-using places and all their possible meanings" (Villani 2006 p. 147).

It will not be a case of building new cathedrals, but rather of opening up some "social interstices"; setting to work open devices, filters that can be passed through, able to open obstructed passages, putting levels of reality kept separate from each other into contact: "autonomous zones of transformation that do not have as their final outcome the totalitarian production of hypothetical promised lands but creative spaces aimed at upsetting the logics of subjection" (Villani 2006, p. 137).

Not show-places, therefore, but places capable of intercepting weak memories and energies dispersed over the territory, where immaterial and imaginary goods can be produced. Places where human relations may be not just represented but directly experienced through subjective appropriation and construction of the space, and where resources otherwise inexpressible may be activated; "architectures not defined by precise functions but available for many different activities, like a computer that responds to a change in needs and necessities, including seasonal ones" (Branzi 2006, p. 132).

In this case, too, it will therefore no longer be a question of just producing objects but, rather, of creating the conditions by inventing spaces that will use time as their main building material, so as to activate new ways of participating in the actual manufacturing processes.

Portals, then, of a capillary network spread over the territory and in continuous and perpetual construction, created via reversible and 'crossable' building systems that are eternally incomplete and imperfect, but fit to be transformed and manipulated over time and capable of combating spectacularisation by producing and inventing veritable devices for existence.

\section{Endnotes}

a"A monody in the language of music is the song of a single voice (carried out by one or more people) with or without accompaniment." See www.treccani/it/enciclopedia.

${ }^{\mathrm{b}}$ As we are taught in music, polyphony as opposed to the monody is a "kind of written music that envisages the simultaneous singing of many voices (human and/or instrumental) at different pitches, which progress in parallel or opposite directions to chant hymns, prayers and songs but also to play concerts and symphonies. In a wider sense polyphony can indicate any vertical aggregation of sounds, such as, for example, a chord in the language of harmony". See www.treccani/it/enciclopedia.

${ }^{\mathrm{c}}$ As Wim Wenders reminds us in his beautiful film "Till the end of the world", after the protagonists have frenetically crossed the world of cities, where high-speed images follow each other and everything seems to merge into a synchronism in which nothing is seen precisely because too much is seen, they are catapulted into the silent Australian desert. In this archaic, very modern space, dominated by the presence of highly advanced immaterial technology, maybe it will be possible to start seeing again. Suddenly, just here, it unfolds that it was perhaps their blind mother who was the one that, without seeing, had understood the most.

\section{Competing interests}

The author declares that she has no competing interests.

Received: 24 February 2014 Accepted: 21 August 2014 Published online: 11 October 2014

\section{References}

Agamben G (2008) Che cos'è il contemporaneo? Nottetempo, Rome

Amin A, Thrift N (2002) Cities. Reimagining the urban. Polity Press, Cambridge Berto G (1999) Freud, Heidegger. Lo spaesamento. Bompiani, Milan

Branzi A (2006) Modernità debole e diffusa. II mondo del progetto all'inizio del XXI secolo. Skira, Milan

Cacciari M (2004) Nomadi in prigione. In: A. Bonomi A., Abruzzese La città infinita. Milan, Bruno Mondadori, Milan, pp 51-59

Calvino I (1992) Saggi 1945-1985. In: Barenghi M (ed). Mondadori, Milan

Choay F (1994) Le règne de l'urbain et la mort de la ville. In: Various Authors La ville. Art et architecture en Europe. Centre Georges Pompidou, Paris, pp 1870-1993

Corzani V (1994) Roland Kirk, John Zorn, Frank Zappa, Beastie Boys. L'Arte del mosaico. Un'icona di fine millennio. In: Foucault M. Eterotopia, Millepiani, n. 2. Mimesis, Milan

Dal Pozzolo L (ed) (2002) Fuori città senza campagna: paesaggio e progetto nella città diffusa. Franco Angeli, Milan

Decandia L (2000) Dell'Identità. Saggio sui luoghi. Per una critica alla razionalità urbanistica. Rubbettino, Soveria Mannelli

Decandia L (2008) Polifonie urbane. Oltre i confini della visione prospettica. Meltemi, Rome

Deleuze G (1981) Francis Bacon. Logique de la sensation. La Différence, Paris

Deleuze G, Guattari F (1980) Mille plateaux. Capitalisme et Schizophrenie, vol. 1. Ed. de Minuit, Paris

Dematteis G (1988) La scomposizione metropolitana. In: Mazza G (ed) Le città del mondo e il futuro delle metropoli. Partecipazioni Internazionali. Esposizione internazionale della XVII Triennale di Milano. Electa, Milan, pp 33-42

Didi-Huberman G (2000) Devant le temps. Histoire dell'art et anachronisme des images. Les Éditions de Minuit, Paris

Donadieu P (1998) Campaignes urbaines. Actes Sud, ENPS Versailles

Eliade M (1965) Le sacré et le profane. Gallimard, Paris

Farinelli G (2003) Geografia. Introduzione ai modelli del Mondo. Einaudi, Turin

Farinelli F (2009) La crisi della ragione cartografica. Einaudi, Turin

Foucault M (1994) Eterotopia. Millepiani, n. 2. Mimesis, Milan

Lefebvre H (1968) Le droit à la ville. Anthropos, Paris

Marin L (1994) De la représentation. Gallimard, Seuil Paris

Merleau Ponty M (1964) L'Oeil et l'Esprit. Gallimard, Paris

Nancy JL (1999) La ville au loin. Fayard, Paris 
Sassen S (2006) Territory, Authority, Rights: from Medieval to Global Assemblages. Princeton University Press, New Jersey, U.S.A.

Sassen S (2012) Cities in a World Economy, 4th edn. Sage Publications, U.S.A.

Secchi B (2000) Prima lezione di urbanistica. Laterza, Rome-Bari

Serres M (1993) Les origines de la géométrie. Tiers livre des fondations. Flammarion, Paris

Soja EW (1989) Postmodern Geographies: The Reassertion of Space in Critical Social Theory. Verso London, New York

Villani T (2006) II tempo della trasformazione. Corpi, territori e tecnologie. Manifestolibri, Rome

doi:10.1186/s40410-014-0012-3

Cite this article as: Decandia: Towards a polyphonic urban score. City, Territory and Architecture 2014 1:12.

Submit your manuscript to a SpringerOpen ${ }^{\circ}$ journal and benefit from:

- Convenient online submission

- Rigorous peer review

- Immediate publication on acceptance

- Open access: articles freely available online

- High visibility within the field

- Retaining the copyright to your article

Submit your next manuscript at $\boldsymbol{\wedge}$ springeropen.com 